\title{
Some Main Causes of Marine Pollution in Vietnam
}

\author{
Cong Tri Tran, Phuoc Quy Phong Nguyen
}

\begin{abstract}
Vietnam is a coastal country located in the central region of Southeast Asia, Vietnam has a sea area connecting the important sea transport route between the Indian Ocean and the Pacific Ocean, especially the East Vietnam Sea are oil and container shipping routes from other countries to Japan, South Korea and China, which are consuming huge amounts of energy. Vietnam is in a position to have a potential for marine economic development such as shipbuilding, sea transport, port development, and waterworks, marine product exploitation, marine and oil and gas resource exploitation, marine tourism and islands, sea services, and other related industries. With such a potential position, the exploitation of the sea and the protection of the marine environment is an extremely important issue.
\end{abstract}

\section{Index Terms-Pollution; Oil Spill; Plastic Waste; Marine.}

\section{INTRODUCTION}

Vietnam is a country with a coastline longer than 3200 $\mathrm{km}$ and the economic region of Vietnam has acreage larger than $1.000 .000 \mathrm{~km}^{2}$ with lots of rich and varied resources such as seafood, coral. In addition, the Vietnam sea area include more than 3000 islands in which has two big archipelago are Hoang Sa (Da Nang) and Truong Sa (KhanhHoa) and some islands that famous for travel such as Tho Chu (KienGiang), Phu Quoc (KienGiang), Cat Ba (Hai Phong),...could see that Vietnam is a one of country received enormous and varied sea resources by nature. In recent years, it seems that resources decrease rapidly and the marine environment of Vietnam becomes serious pollution. So, why is the cause of such a large resource that is slowly exhausting and standing in front of such severe pollution? And need any solutions to prevent, minimize the risk [1]-[3].

Now, the sea of Vietnam area is in front of the risk of becoming depression and high pollution. This is shown by the seafood - the main income of fisherman becoming exhausted, the phenomenon of fish died massively and then drift into the coast of the sea. In addition, the sea of Vietnam pollution is also present by scientific reports when the concentration of TSS such as $\mathrm{Si}, \mathrm{NO} 3, \mathrm{NH} 4$, and PO4 also at a worrying level [4],[5]. The content of monitoring parameters such as COD, $\mathrm{NH}_{4}$ in the period of 2011-2015 in most areas has reached a high level of Vietnam Standards. According to Unicef, water pollution is now happening all over the world, especially in developing countries like in the Sahara, Southeast Asia and Latin America. Since 2016, the international environmental organizations have alarmed China, Indonesia, the Philippines, Thailand and Vietnam are standing in the top 5 countries with the largest amount of waste dumped into the world.

Published on March 27, 2019

Cong Tri Tran and Phuoc Quy Phong Nguyen are with Ho Chi Minh City University of Transport, Ho Chi Minh City, Vietnam.
There is a sad situation in Vietnam that the act of discharging waste into rivers and lakes and the sea has become a familiar image for people. Forms of sanctions, reminders and administrative fines have become too light, not deterrent to violations [6],[7]. The fact that the Thi Vai river has been "suicide" by chemicals discharged from Vedan factory for 14 consecutive years is always a concern of environmental lovers in Vietnam. However, after the Thi Vai River, our country still witnesses many other rivers and seas each year under similar circumstances [8],[9].

The water of the sea in some areas has an expression that is acidic because the $\mathrm{PH}$ in the sea surface varies relatively high. The coastal seawater has an expression of contamination by organic matter, zinc $(\mathrm{Zn})$, some of the vaccine protection of plants [10],[11]. Biodiversity of the seabed and descending plants were remarkably diminished. The red tide phenomenon has appeared in the South Central sea, especially in Khanh Hoa, Ninh Thuan, Binh Thuan that killed many kinds of fish, shrimp that is cultivated in the areas, the situation of fisherman has used fishing tool that has destruction of nature happening in a common way such as impulse, explosives, high-pressure lights are too power to allow exhausting of coastal seafood gains.

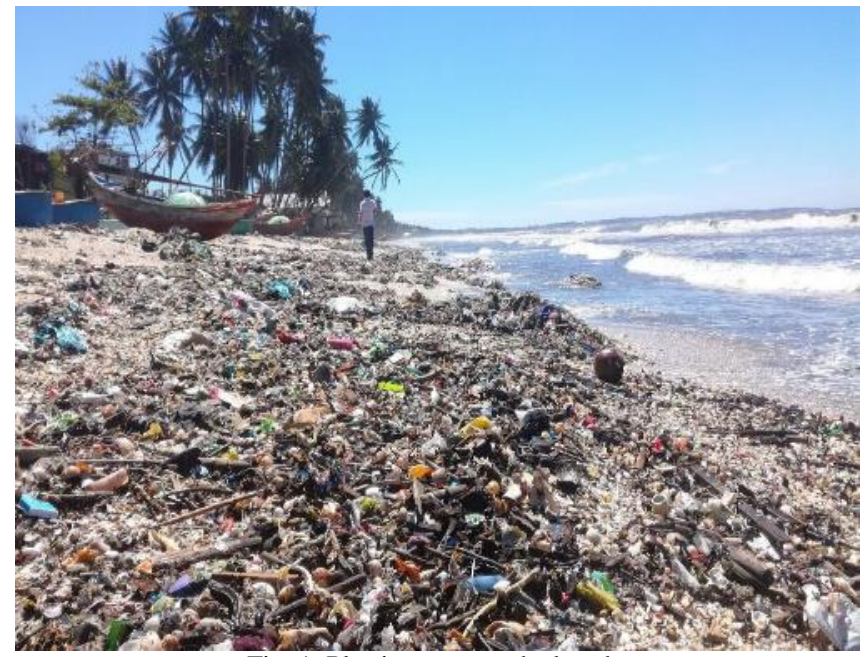

Fig. 1. Plastic waste on the beach

According to the statics of the Ministry of Natural Resources and Environment shows that about $70 \%$ of the waste pouring out of the sea from land by the factory, enterprise, residential areas, hospitals, agricultural production...Most of these waste have not been processed, through the drainage system straight out to the rivers, many rivers straight out to the sea, carrying a large variety of substances, plastics, chemicals, metals, oil residue, even radioactive substances. So, pollution by organic substances in the coastal seawater has been happening in a common way in the coastal cities [12],[13].

Vietnam's sea now in addition to water pollution, the 
exploitation of marine products are now emerging to a more disturbing event that is exploiting indiscriminately and unauthorized coral reefs. As known, The coral has an extremely important role in the protect aquatic of seafood and develop tourism [14],[15]. In addition to producing organic compounds that provide food not only for the coral reefs and hundreds of types of creatures to reside, feed and spawn, raise larvae and distribute the same source but also the photosynthesis of the symbiotic algae A nutritional cycle, the high elementary product folding 10-100 times There are no coral reefs for the surrounding marine environments. The coral reefs are also developing economic tourism with the type of swimming pool, photographic, filming, Discovery... According to scientists ' estimates, the average $1 \mathrm{~km} 2$ of coral reefs can generally bring 108,000 USD from the exploitation of aquatic resources and 400,000 USD from tourist activities [16],[17]. But because of the current demand in the exploitation of coral to do the decorations in the house, the type of jewelry. Many of the coral-mining fishermen have used these measures to enhance the performance of coral exploitation. According to the statistics, assessment of marine environmental specialists, within 15 years back here, about $15-20 \%$ of the coral reefs have been lost due to the implications of the natural and the human being, concentrated mainly in populated areas of living Concentrated as Halong Bay-Cat $\mathrm{Ba}$, the central coastal province from Da Nang to Binh Thuan, and some of the islands of the Truong Sa and island districts.

\section{The CAUSES OF MARINE EnVIRONMENTAL POLlution}

Current situation: Vietnam Sea is in alarming pollution due to air and human impact. $90 \%$ of the water in ponds, lakes and rivers flows into the sea without being processed. Most of the continental waste flows by rivers, streams, waste from human activities on the sea: Such as mining, sea transportation ... are threatening the ecology of the region. sea. Statistics show that Vietnam's coastline is longer than 3,260 kilometers, passing through 28 provinces and cities along the length of the country. The total number of pools and coves is 44, over 2200 coastal islands, 1120 coral reefs, more than 250 thousand hectares of mangrove forests. Some coastal areas are being chiseled, the amount of suspended sediment greatly affects the photosynthetic capacity of some marine organisms and degrades the source of natural seafood. The seawater of some areas shows acidification because the $\mathrm{pH}$ in the sea water surface changes relatively high. The coastal sea water is shown to be contaminated by organic matter, zinc $(\mathrm{Zn})$, some plant protection drugs. Biodiversity of northern coastal animal fauna and floating plants in the Central region declined markedly. Red tide phenomenon has appeared in the South Central Coast waters, killing all kinds of fish and shrimp cultured in these areas, the situation of fishermen using fishing tools Destructive fishing is quite common such as electrical impulses, explosives, high-pressure lights exceeding the permitted capacity depleting coastal marine resources.

\section{A. The source from mainland emissions}

The main cause of the Vietnamese marine environment pollution is now mainly from the mainland, where factories, factories, industrial zones to crowded residential areas operate daily. This amount of waste accounted for about $70 \%$ of sea garbage. Notably, Vietnam currently has more than 280 industrial zones with more than $550.000 \mathrm{~m} 3$ of wastewater/day nights; 615 the industrial cluster but in which only about $5 \%$ are concentrated wastewater treatment systems. More than 500,000 production facilities including the various types of environmental pollution production, obsolete production technology [18]. Not to mention factories, enterprises that produce daily medical devices arise more than 47 tons of hazardous waste daily and $125,000 \mathrm{~m} 3$ of medical wastewater. Most of this wastewater cannot be handled and discharged directly into the sea or the large rivers connecting to the sea. Viet Nam has more than 100 large rivers connecting with the sea with water flow to the annual sea of $880 \mathrm{~km}^{3}$ of water. This pulls in many substances can pollute the sea as organic, nutrient, metallic substances. In addition, natural disasters also impact the cause of serious environmental conditions for Vietnam's marine environment.

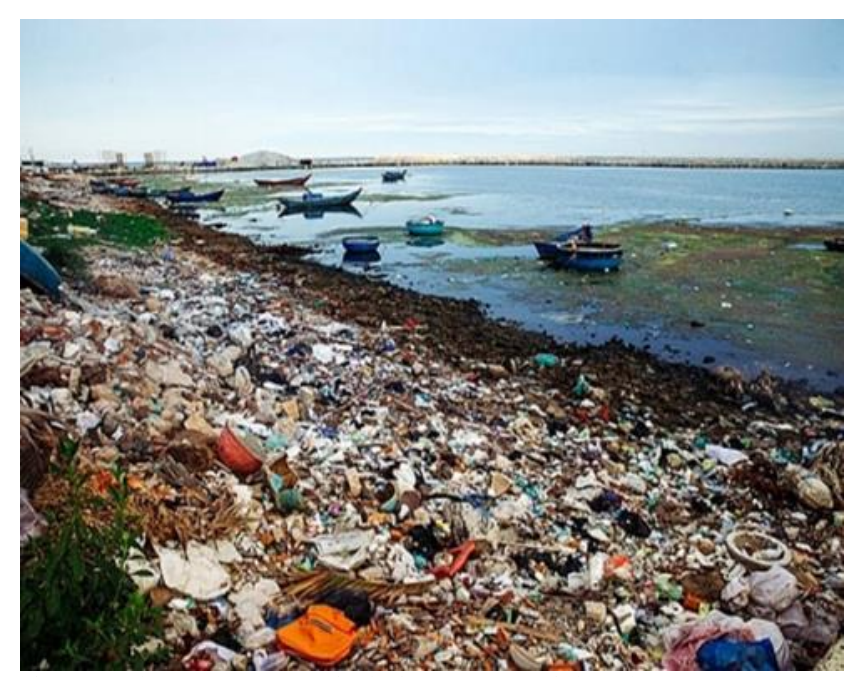

Fig. 2. Garbage Dumps Vertical Line Jetty an Vinh and Ly Son Commune

The most prominent example of the years back here on the direct discharge of industrial wastewater did not over process the rivers certainly could not fail to mention Central sea environmental incidents due to industrial wastewater of Hung Nghiep Steel Co., Ltd Formosa Ha Tinh was caused in 2017 , the waste of Vedan company to the ThiVai river in 2008 or most recently in 2018 is the incident of two livestock enterprises in Bac Giang province, namely Rural Technology Development Joint Stock Company and Hoa Phat Bac Giang Breeding One Member Co., Ltd. discharging into the environment in excess of regulations allow. 


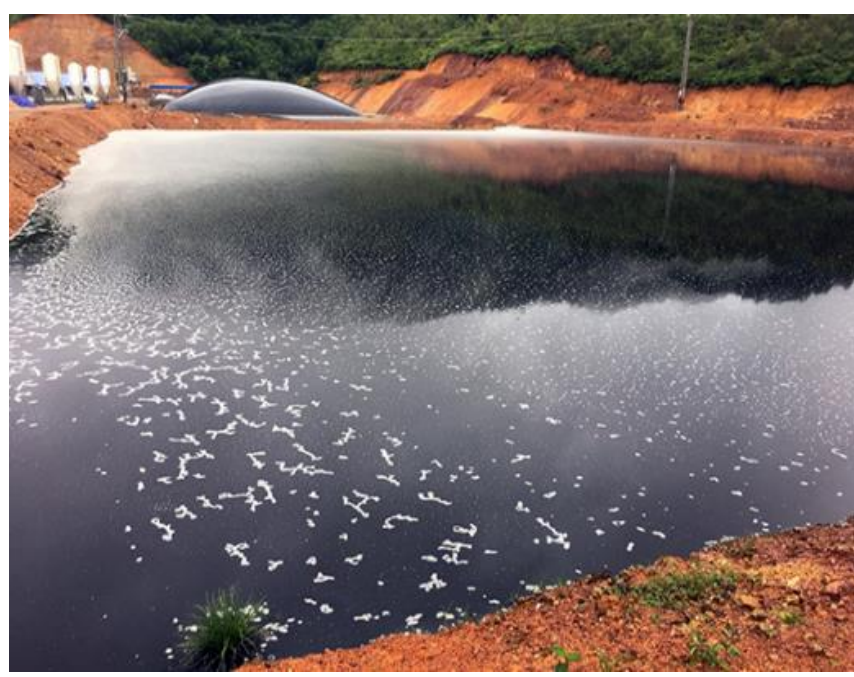

Fig. 3. Raising sewage water is discharge straight to the reservoir, not over process

B. Marine environmental pollution due to oil spilling problems

Oil spills pollute the marine environment, seriously affecting ecosystems. Especially seagrass, sandbanks, lagoons, and coral reefs. Oil pollution reduces the ability of resilience, flexibility, and resilience of ecosystems. High oil content in the water, oil films reduce the ability of oxygen exchange between air and water, reduce oxygen in the water, causing the balance of oxygen regulation in the ecosystem to be overturned.

In addition, oil spills contain toxins that damage the ecosystem, which can cause ecosystem degradation. Because oil contains many different ingredients, altering, destroying cell structure, sometimes killing the whole population. Oil seeps into the sand, sludge in the seaside can affect for a very long time. There have been many cases where the species died massively due to the impact of the oil spill.

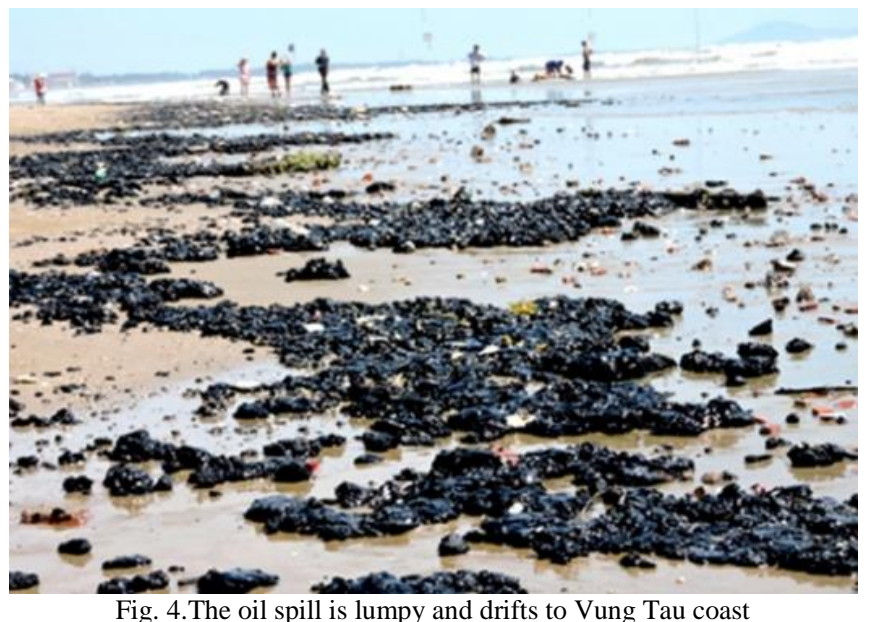

In Vietnam, the amount of oil spilled starts from many different causes such as ship collision at sea or due to the search, exploration, exploitation, transport, processing, distribution and storage of oil and other product of oil. In addition, some natural factors cause oil spills such as earthquakes. Accordingly, the main causes of the cause of the spill are:

+ Rise in the ceiling, lack of traffic control and a full measure of air kneel on some of the mounds.

+ Cleaning by sea sanitation

+ As the process of extraction and processing of go in drilling and coastal facilities

Currently, Vietnam has over 1,700 transport ships, along with the number of fishing vessels of about 130,000 vessels, corresponding to the amount of fuel consumed about 4 million tons/year. It can be said that this is the source of pollution for the seas, coastal areas, and many places, seriously affecting the marine ecosystem, destroying marine resources, endangering human health

\section{Marine environmental pollution due to the fishery industry}

Aquaculture on cages and rafts on the coast is a breakthrough foraquaculture industry. But it is not that there are no shortcomings about environmental issues when doing this. The most outstanding example is the shrimp farming households. In the process of improving shrimp farming, some households use chemicals to improve with common chemicals such as lime, iodine, chlorine, saponin ... The use of such chemicals will more or less work. moving to the environment [19]-[21]. In addition, households raising large and concentrated aquatic products and emissions occur for a long time, causing pollution to the coastal environment, causing eutrophication, affecting the growth and development of the source.

\section{Marine environmental pollution due to ship demolition}

The old ship dismantling industry can benefit a number of businesses and provide a part of raw materials for the steel industry, however during the ship demolition process will generate a lot of hazardous waste, photos. seriously affect the environment and human health. Especially when the infrastructure of enterprises dismantles old and obsolete old ships, they are not interested in investing in technology to treat and overcome the consequences of environmental pollution.

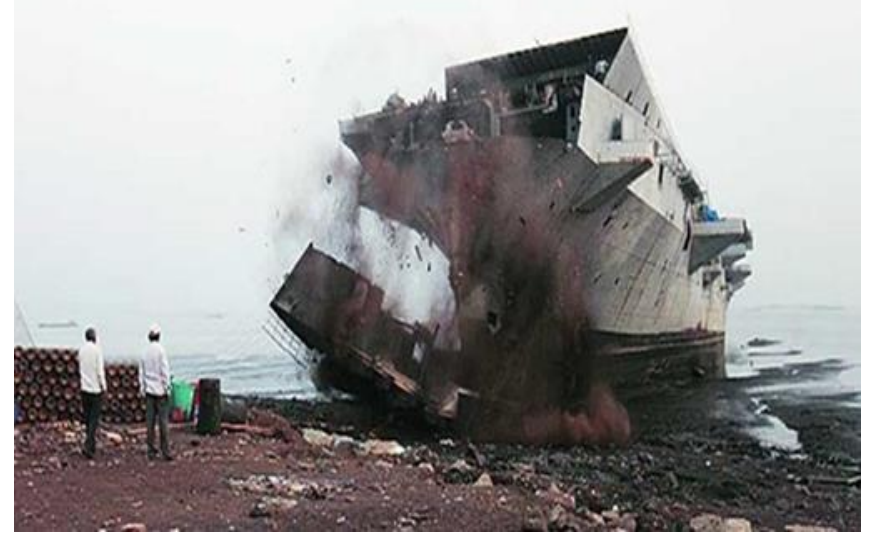

Fig. 5. Demolition of old ships causes environmental pollution

Ship demolition activities produce toxic chemicals and hazardous wastes such as PCB, PVC, PAH, TBT, mineral oil, asbestos, heavy metals (mercury, lead, copper, zinc, aluminum, iron ...) and other hazardous substances such as radioactive substances, organic cyanide compounds and vessel ballast deposits containing many foreign bacteria and 
organisms [22]. That is not to mention the danger of dismantling ships carrying oil, chemicals, radioactive substances, waste or other dangerous goods.

Currently, there are many facilities that operate ship demolition but do not have a license to operate. This has also greatly influenced the marine environment.

\section{E. Marine environmental pollution due to release ballast water}

Statistics from the United Nations Environment Program (UNEP) said that the source of marine pollution from shipping and traveling activities on the sea accounts for $18 \%$ of the total waste

Monitoring indicators in ballast water indicate that they are contaminated by oil, metals $(\mathrm{Cu}, \mathrm{Zn})$. Compared to the permitted target, the pollutant content exceeds the standard many times. There are thousands of aquatic species transported in ballast water, basically species of small enough size to be able to pass through the intakes and pump ballast water. These include bacteria, other microbes, eggs, and small invertebrates, follicles, and larvae of different species contained in the sludge of ballast water. The deposition and accumulation process of many reservoirs and containing many types of water in geographic areas around the world creates the risk of causing ecosystem impacts when harmful organisms escape.
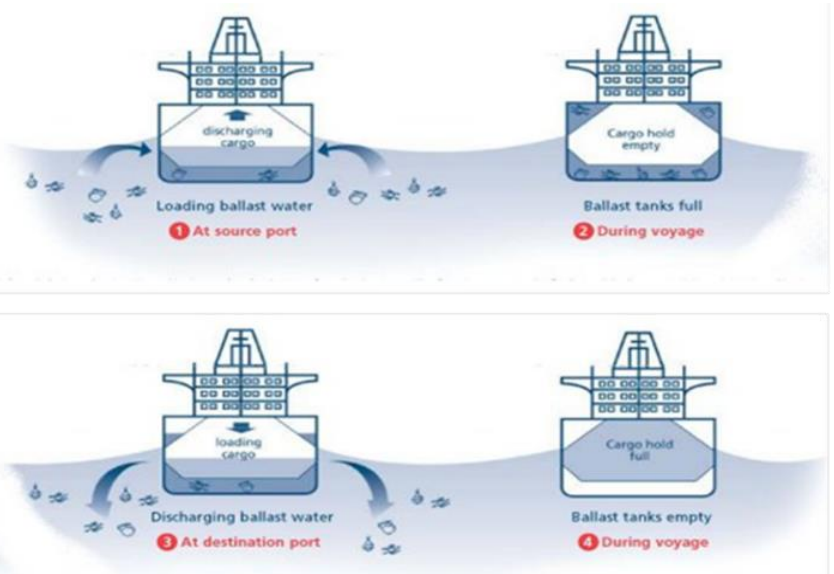

Fig. 6. The process of entering and discharging ballast water into the marine environment

\section{EFFECTS OF MARINE ENVIRONMENTAL POLLUTION ON VIETNAM}

Pollution of the marine environment leads to very serious consequences. It directly harms human health and gradually loses marine resources such as seafood, marine tourism, etc. There are about 100 species of seafood at different endangered levels and over 100 species have been included in the Vietnam Red Book.

The first difficulty is the marine biodiversity and declining aquatic resources. Important marine ecosystems are degraded, lost their habitats and narrowed their area. The populations tend to move further offshore due to changes in coastal circulation structure related to climate change, changes in river and sea interactions in coastal estuaries, due to loss of up to $60 \%$ of habitats Important natural residence.

Next is the impact on the marine tourism industry of our country today [23],[24]. Having the advantage of the coastal road as well as the rich island system, islands, the marine tourism industry in Vietnam will have strong development steps but will be repelled by sea pollution. Accordingly, very famous beaches in Vietnam such as Do Son (Hai Phong) or Vung Tau (Ba Ria - Vung Tau) or Nha Trang (Khanh Hoa) are heavily polluted. According to the annual environmental monitoring results on the environmental status of Ba Ria - Vung Tau province, the quality of seawater in beaches, such as Long Hai, Ho Coc, Bai Sau, Bai Dau, and Bai Dau are all marked. the effect of environmental pollution. Statistics of the Management Board of Nha Trang Bay Marine Protected Area, about 10 tons of tourism waste per day, plus domestic waste, residents' toilets poured into the sea.

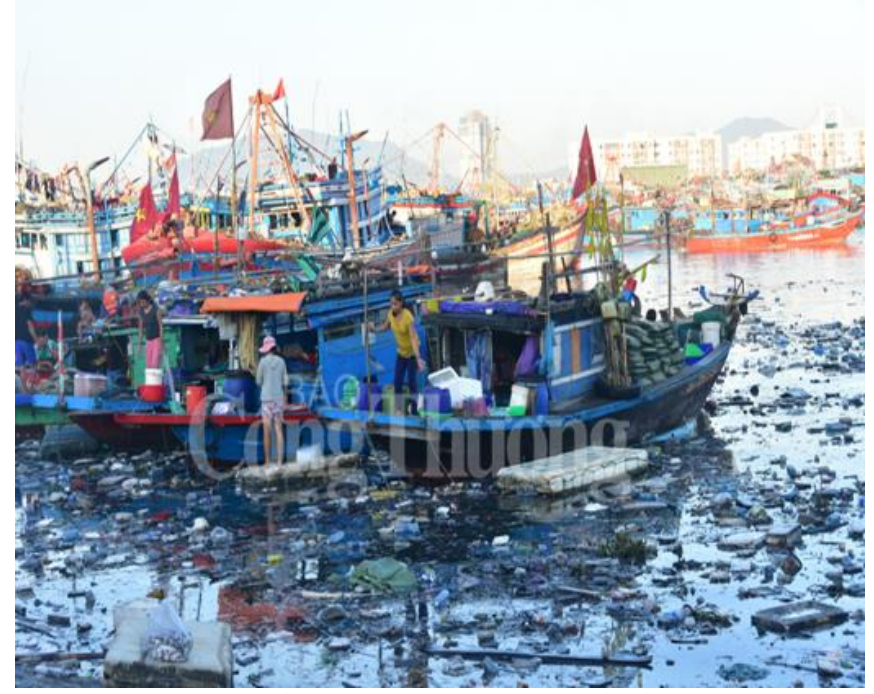

Fig. 7. Pollution of the sea at anchoring places for fishing vessels

In addition, marine environmental pollution also leads to coastal erosion: Nam Dinh has more than $25 \mathrm{~km}$ of dikes that are threatened by erosion. Sand dunes in Tam Giang and Quang Nam and Quang Binh lagoons are also losing changing the geomorphology of coastal areas.

\section{SOLUTION}

Develop and apply strong economic tools in the management of marine, coastal and island environments such as pollution fees, discharge fees, sea use fees, product fees, and administration fees approval, taxes, licensing and revocation of permits for sea, coastal and island exploitation, use of environmental funds and other grants ...

Use beneficial aquatic plants to remove nutrients and organic nutrients in the water. It is necessary to protect the coastal forests and actively plant trees to limit the process of leaching the soil to the sea and the dumps of the mining mines. Avoid using and discharging waste plastic, garbage with long decomposition time into the sea. 
The Countries Polluting The Oceans The Most

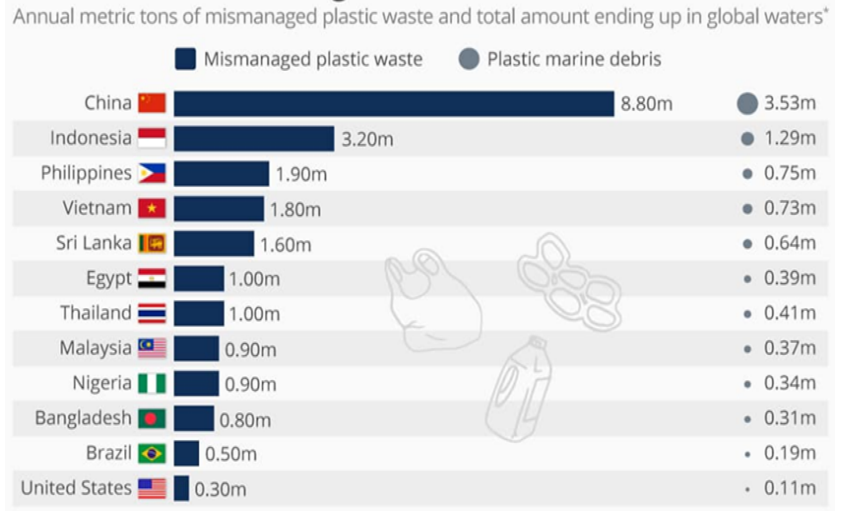

()ㅜㅇㅛ $\odot$ * Generated in 2010 (selected countries

statista

Fig. 8. Vietnam enters the top 4 most plastic wastewater discharges to the sea

Organize propaganda and education for fishermen who are aware of the exploitation of seafood with environmental protection. Regular patrols and controls on the territorial sea check vessels capable of using eradication methods and take measures and penalties deserve this.

- It is necessary to have a long-term overall strategy to protect the marine ecological environment.

- Establish a National Oil Spill Prevention and Response Plan. Prevent industrial zones from discharging dirty wastewater, ponds, lakes, rivers and streams into the sea.

- Use beneficial aquatic plants to remove nutrients and organic nutrients in the water. It is necessary to protect the coastal forests and actively plant trees to limit the process of leaching the soil to the sea and the dumps of the mining mines.

- Raise awareness of the community in protecting the marine environment. Building system of policies, laws and education on marine environmental protection. To renovate the unused land areas along the coast such as digging canals leading into sea water and replanting mangrove forests.

- Do not litter, discharge waste water into rivers and seas without treatment.

- Strict in navigation, avoiding accidents and oil spills.

- Proper exploitation of aquatic products.

- To reasonably exploit sea and island tourism.

- There are policies and regulations to protect the island.

- Touching people with the sense of protecting the marine environment.

- Integrating climate change adaptation issues into policies, planning and management of marine resources and environment.

- Construction of infrastructure to prevent natural disasters, disasters, prevent coastal erosion, protect population, respond to climate change.

- Promote investigation, survey, observation and research on marine resources and environment for sustainable use of natural resources and environmental protection.

- Strengthening the construction and management of marine environmental resources database to rationally exploit and use natural resources and protect the environment.

- Strengthening education and training to develop marine human resources for investigation, research and management of marine resources and environment.

- Promote international cooperation on the sea.

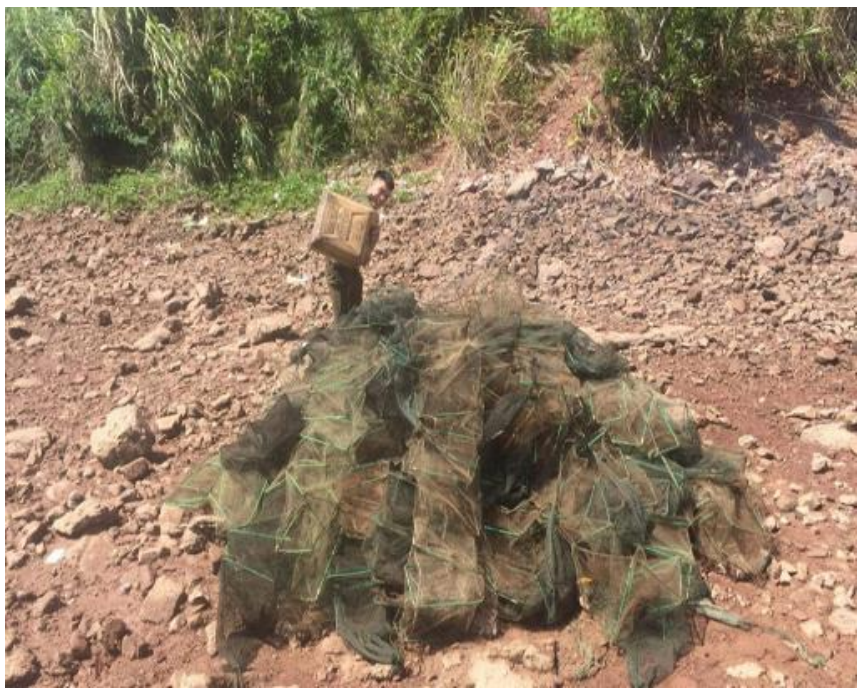

Fig. 9. Destruction of fishery exploitation tools not in accordance with the law

\section{CONCLUSION}

Sea is a precious and vast resource but not endless. If not knowing how to exploit and protect the marine environment appropriately, it will lead to serious pollution of the marine environment. Vietnam is a country with a coastline and a rich and diverse marine life system. But with the current state of the marine environment of Vietnam, not only marine pollution is a problem for the whole society but it will lead to unforeseen consequences for the living environment of all people. like the socio-economic situation of countries. Therefore, it is necessary to take measures to minimize the pollution of the marine environment as well as educate people who have a sense of preservation of the marine environment. Raise awareness of the community in protecting the marine environmentin the situation that the resources are gradually becoming scarce and the situation is changing Climate change is becoming increasingly complex not only in Vietnam but also worldwide.

\section{REFERENCES}

[1] P. S. Daling and G. Indrebo, "Recent improvements in optimizing use of dispersants as a cost-effective oil spill countermeasure technique," in SPE Health, Safety and Environment in Oil and Gas Exploration and Production Conference, 1996.

[2] A. T. Hoang and X. D. Pham, "An investigation of remediation and recovery of oil spill and toxic heavy metal from maritime pollution by a new absorbent material," J. Mar. Eng. Technol., 2018.

[3] V. vang Le and Anh Tuan Hoang, "Marine pollution and remedies of Vietnamese Government," Int. J. Recent Eng. Res. Dev., vol. 2, no. 4, pp. 51-55, 2017.

[4] I. B. Ivshina et al., "Oil spill problems and sustainable response strategies through new technologies," Environ. Sci. Process. Impacts, vol. 17, no. 7, pp. 1201-1219, 2015.

[5] A. T. Hoang, "A report of the oil spill recovery and treatment technologies to reduce the marine environment pollution," Int. J. eNavigation Marit. Econ., vol. 9, pp. 35-49, 2018.

[6] T. Arbatan, X. Fang, and W. Shen, "Superhydrophobic and oleophilic calcium carbonate powder as a selective oil sorbent with potential use in oil spill clean-ups," Chem. Eng. J., vol. 166, no. 2, pp. 787-791, 2011.

[7] M. Fingas, Marine Oil Spills. MDPI, 2018.

[8] Y. Si-Zhong et al., "Bioremediation of oil spills in cold environments: 
A review," Pedosphere, vol. 19, no. 3, pp. 371-381, 2009.

[9] C. Gasparotti, "Risk assessment of marine oil spills.," Environ. Eng. Manag. J., vol. 9, no. 4, 2010.

[10] X.-Q. Le, V.-H. Vu, L. Hens, and B. Van Heur, "Stakeholder perceptions and involvement in the implementation of EMS in ports in Vietnam and Cambodia," J. Clean. Prod., vol. 64, pp. 173-193, 2014.

[11] A. T. Hoang, V. V Pham, and D. N. Nguyen, "A report of oil spill recovery technologies," Int. J. Appl. Eng. Res., vol. 13, no. 7, pp 4915-4928, 2018.

[12] P. H. Hoang, A. T. Hoang, N. H. Chung, L. Q. Dien, X. P. Nguyen, and X. D. Pham, "The efficient lignocellulose-based sorbent for oil spill treatment from polyurethane and agricultural residue of Vietnam," Energy Sources, Part A Recover. Util. Environ. Eff., vol. 40, no. 3, pp. 312-319, 2018.

[13] A. T. Hoang, X. L. Bui, and X. D. Pham, "A novel investigation of oil and heavy metal adsorption capacity from as-fabricated adsorbent based on agricultural by-product and porous polymer," Energy Sources, Part A Recover. Util. Environ. Eff., vol. 40, no. 8, pp. 929 939, 2018.

[14] A. T. Hoang et al., "An absorption capacity investigation of new absorbent based on polyurethane foams and rice straw for oil spill cleanup," Pet. Sci. Technol., vol. 36, no. 5, pp. 361-370, 2018.

[15] Western Canada Hydraulic Laboratories Ltd, "Investigation of the operating parameters of the oil spill containment and recovery (OSCAR) Vessel, Environment Canada Technology Development," 1981.

[16] V. Vodyanoy, O. Pustovyy, T. Moore, and K. Brock, "Passive oil collection device," no. January 2015, 2013.

[17] H. Anh Tuan and C. Minh Quang, "A mini review of using oleophilic skimmers for oil spill recovery," J. Mech. Eng. Res. Dev., vol. 41, no. 2, pp. 92-96, 2018.

[18] A. H. Hammoud and M. F. Khalil, "Performance of a rotating drum skimmer in oil spill recovery," Proc. Inst. Mech. Eng. Part E J. Process Mech. Eng., vol. 217, no. 1, pp. 49-57, 2003.

[19] A. T. Hoang and M. T. Pham, "Influences of heating temperatures on physical properties, spray characteristics of bio-oils and fuel supply system of a conventional diesel engine," Int. J. Adv. Sci. Eng. Inf Technol., vol. 8, no. 5, pp. 2231-2240, 2018.

[20] A. T. Hoang, "Prediction of the density and viscosity of biodiesel and the influence of biodiesel properties on a diesel engine fuel supply system," J. Mar. Eng. Technol., 2018.

[21] A. T. Hoang and A. T. Le, "A review on deposit formation in the injector of diesel engines running on biodiesel," Energy Sources, Part A Recover. Util. Environ. Eff., vol. 41, no. 5, pp. 584-599, 2019.

[22] A. T. Hoang and D. C. Nguyen, "Properties of DMF-fossil gasoline RON95 blends in the consideration as the alternative fuel," Int. $J$. Adv. Sci. Eng. Inf. Technol., vol. 8, no. 6, pp. 2555-2560, 2018.

[23] V. V. Le and A. T. Hoang, "Fuel and alternative fuel for marine diesel engines," Int. J. Recent Eng. Res. Dev., vol. 2, no. 7, pp. 142-146, 2017.

[24] A. T. Hoang and V. T. Nguyen, "Emission Characteristics of a Diesel Engine Fuelled with Preheated Vegetable Oil and Biodiesel," Philipp. J. Sci., vol. 146, no. 4, pp. 475-482, 2017. 